\title{
Development of modern forms of hotel farm in the region
}

\author{
Antonina Petrenko ${ }^{1 *}$, Galina Ekinil ${ }^{1}$, Valeria Provotorina ${ }^{1}$, and Ekaterina Davidova ${ }^{1}$ \\ ${ }^{1}$ Don State Technical University, Gagarina Sq., 1, Rostov-on-Don, 344000, Russia
}

\begin{abstract}
Analyst research is aimed at analyzing the features of the hotel industry in the city of Rostov-on-Don and the Rostov region and identifying new forms of organizing hotel economy with elements of cooperation and integration. The article has been an assessment of modern Russia's eco-hotels, the geography of their distribution, and also studied the range of hotel services provided by them. Based on the assessment, the prospects for the development of a business idea for the Russian hotel business were revealed.
\end{abstract}

\section{Introduction}

Modern tourism today can take various forms to be attributed to the traditional visit to museums, historical places, and concert programs dedicated to traditional folk culture. Currently, especially among young people, thematic ethnographic parks or individual rides, organized in park areas, cities, museums, reserves (examples of such parks and attractions can be found in the Rostov region in Tanisa, in P. Abrau on the Black Sea coast, in the reserve in P. Revival in Gelendzhik, etc.). In such parks, local residents organize exhibitions and fairs of objects of traditional culture, create reconstructions of household situations. Visitors can participate in traditional technological processes or rituals.

Inter-ethnic communication in tourism on a deeper and substantial level can manifest itself by communicating with a guide / carrier translator of ethnic culture, with the local population in the process of household actions (for example, visits to public catering, shopping, etc.), with carriers of ethnic culture In the course of cultural, sports, scientific, educational events (festivals, competitions, scientific conferences, training camps), accommodation surrounded by carriers of culture (for example, eat housing from the local population), cultural exchange programs (accommodation in local families for a sufficiently long period - From several weeks to several months), leisure communication with the carrier friends of the local culture.

In recent years, the sphere of Russian hotel business has undergone major changes and today mainly complies with international standards for the quality of service, interior design and staff skills. At the same time, the need to build new hotels is still relevant, since old typical buildings, even upgraded, retain the patina of times when the comfort was not a priority.

This is also visible on the layout, and the location of the windows, and the size of the

\footnotetext{
* Corresponding author: takyin_d@mail.ru
} 
room. New architectural and design solutions make it possible to feel comfortable even in small rooms with a modest, but fundamentally new situation. Construction of new hotel complexes with a well-maintained territory, developed infrastructure, convenient access roads is the most important feature of the modern hotel business.

The demand for hotels located in distant areas and roads depends on the quality of services and the number of services, price levels and comfortable conditions. Many small private hotels have gained great popularity through a delicious and inexpensive kitchen, high level of organization of holidays and business events.

The relatively new proposal in the hotel business market are campgrounds with comfort - glhamping, where urban comfort and pristine nature are organically combined.

Such a format of residence conquers more and more admirers due to a comfortable organized rest in the wild with elements of aesthetics of five-star hotels. This is a great way to plunge into a completely different atmosphere and philosophy of rest. With the point of view of trends, glumpingizing the consumer expectations of novelty - give the maximum variety of natural landscapes and placement conditions.

Taking into account the concept of sustainable development of tourism, the existing socio-economic realities of glampinggi are the most promising format of accommodation means for the construction of the region's natural territories.

The purpose of the work is the analysis of the specifics of the activities of glumpings as a modern form of organizing hotel farm in the region, a study of their influence on the development of the tourist industry of the Rostov region.

Given the prospects for the development of tourism in the territory of the Rostov region, it is necessary to summarize the experience of foreign countries in which such tourist projects are most successfully implemented.

\section{Materials and methods}

To date, tourism and hospitality industry are among the most actively developing industries that bring good income.

The issues of studying the trends and features of the development of hotel business worldwide and in Russia are devoted to the work of such authors as: A.O. Nabil, Channouf Asma Al-Zaidi, 2016 [1], Mehmet Ali Köseoglu, Mehmet Altin Eric Chan, Omer Faruk Aladag, 2020 [2], M. S. Oborin, 2018 [3], S. N. Moreva, E. V. Zobova, E. V. Zobova, L. A. Yakovleva, 2017 [4], N.Y. Goryushkina, D.V. Shkurkin, A.S. Petrenko, S.Y. Demin, N.S. Yarovaya, 2016 [5].

The methodology for tourism research in the context of regional specifications is devoted to the work of such authors as: S. Karampela, D. Kavroudakis, T. Kizos, 2019 (Experience of Greece) [6], T.Y. Dewanti, D. Susiloningtyas, Supriatna, 2019, (Experience Indonesia) [7], S. Li, C. Li, J. Li, 2019, (China's experience) [8], J. Cheng, Jingxu, Zhenfanghuang, 2019 [9], Samichaabouni, 2019 [10], Virgilnicula, Simonaspânu, RoxanaelenaAgu, 2013, (Experience Romania) [11], DanieladoinaFundeanu, 2015 [12], HAM Shaffril, A. Hamzah, S.MD. Yassin, B.A. SAMAH, J.L. D'Silva, N. Tiraieyari, M. Muhammad [13].

Analysis of the hotel services market and the prospects for its development in the Rostov region are devoted to the work of such authors as L.N. Kazmina, V.S. Makarenko, V.V. Provotorina, T.N. Grigorenko, G.E. Ekinil, E.M. Shevchenko, A.S.Petrenko [14, 19, 16-19].

The tourist industry is one of the most profitable sectors of the global economy and plays an important, and sometimes the main role in the formation of gross domestic product, strengthen the trade balance, creating additional jobs. Despite the presence of modern hotel complexes with a developed infrastructure, in recent years, tourists began to 
be interested in new forms of hotel economy. Many travelers love places distant from civilization, single-eyed with nature. Hiking with backpacks and tents are ideal for such purposes. However, modern people are accustomed to comfort and all sorts of amenities. Now we are increasingly harder to abandon gadgets, the Internet and other benefits. It is in order to make such a vacation in nature more comfortable, and made glinding.

Learning the features of the functioning of glompings in world practice are devoted to the following authors in world practice: Edward Brooker, Marion Joppe, 2013 [20], Kevin Grande, 2021 [21], Christopher A.Craig, 2020 [22], Ana Brochado, Cristina Pereira, 2017 [23].

Glamping allows tourism, not depriving itself of elementary amenities, such as: a comfortable bed, a hot shower and a comfortable toilet. This kind of recreation is suitable even to those people who are accustomed to luxury conditions.

The new word "Glamping" comes from the phrase "glamorembembing". Glamping is rooted in ancient times. When the rulers traveled in their possessions, even whole temporary settlements were formed, which were subsequently became cities. Glamping began to develop in the UK for about 15 years ago. Initially, it was considered an exotic view of rest for wealthy tourists who could explore remote natural corners of the country, living not in tents, but in small capposlands houses, with a high level of service and nutrition. To get to such glumping camps, tourists had to spend a lot of money. If before, not many travelers could afford such a vacation, now he has already been distributed in the UK, USA and Australia. The United Kingdom still remains the leader of the global glinding market. Glamping is a vacation in nature with all the amenities and full hotel service. Another important condition of glinding is to be mobile and organically fit into the environment, without harming it.

The characteristic features of the glinding include:

- remoteness from civilization. As a rule, Glamping implies the inaccessibility of location locations, there are no other means of accommodation, asphalt roads;

- authenticity, reflecting the originality and flavor of local culture;

-Exology (buildings do not harm the environment).

Maximum caring attitude towards nature is the basis of glinding movement. The environmental friendliness of the tour enterprise and environmental consistency is one of the foundations of the format that is focused on the future generation, but is also suitable for an adult audience.

The study methodology is based on the application of a comparative analysis method that has allowed to analyze the types of glumpings and geography of their distribution in Russia, the degree of provision of the company in the city districts of the Rostov region in order to identify the prospects for the development of glempings in the Rostov region. The method of promising planning was used to develop recommendations for organizing the activities of the glepping on the territory of the Rostov Region in order to develop tourist infrastructure in the areas of hotel and tourist services removed from the center and laxifications. Scientific regulations, conclusions and recommendations contained in the article are based on the use of the method of logical analysis and the economic and statistical method.

\section{Results}

Glampings have all signs of a comfortable hotel: a reception, a comfortable sleeping place, a comfortable bathroom, a shower, a restaurant, daily housekeeping. But, unlike regular hotel, in Glamping is always a chic look from any window, the environmental component is carefully thought out, the maximum proximity to life in nature is preserved, the civilized glinding conditions are so organically inscribed in the surrounding landscape that they 
become completely invisible. In world practice, glumpings are presented a variety of objects of objects, relevant standards (Table 1).

Table 1. Types of glumpings and their characteristics.

\begin{tabular}{|c|c|c|c|c|}
\hline № & Type & Description & $\begin{array}{c}\text { Capacity, } \\
\text { people }\end{array}$ & $\begin{array}{c}\text { Cost } \\
\text { rub./night }\end{array}$ \\
\hline 1 & 2 & 3 & 4 & 5 \\
\hline 1 & Ecodom & $\begin{array}{l}\text { Spherical or cubic designs with } \\
\text { glass walls. }\end{array}$ & $2-4$ & from 2500 \\
\hline 2 & $\begin{array}{l}\text { Trails and } \\
\text { mobile trailers }\end{array}$ & $\begin{array}{l}\text { Fucks equipped with all the } \\
\text { comforts. Filized trails are put in a } \\
\text { picturesque place, a common } \\
\text { veranda is equipped. }\end{array}$ & $2-4$ & from 2000 \\
\hline 3 & EcoPheremum & Stylized houses on a farm. & $25-28$ & from 4000 \\
\hline 4 & Ecochapsula & Stationary Tents Breathable Tree. & 2 & from 2000 \\
\hline 5 & $\begin{array}{l}\text { Houses on the } \\
\text { trees }\end{array}$ & $\begin{array}{l}\text { Ready house on tree with all } \\
\text { comfort. }\end{array}$ & 2 & from 3000 \\
\hline 6 & Tent Glampings & $\begin{array}{l}\text { Large tents consisting of a wooden } \\
\text { high frame and stretched awning. }\end{array}$ & $2-4$ & from 2500 \\
\hline 7 & Yurts & $\begin{array}{l}\text { Frame from bent rails and bars, on } \\
\text { top of which mat is stretched. } \\
\text { Housing reliably protects from } \\
\text { winds, rains and sun. }\end{array}$ & $2-4$ & from 3000 \\
\hline 8 & Forest hut & $\begin{array}{l}\text { Traditional housing, the most } \\
\text { inscribed in the natural landscape. }\end{array}$ & 2 & from 3000 \\
\hline 9 & Tipi & $\begin{array}{l}\text { A round tent, at the base of which } \\
\text { there is a cone, consisting of } \\
\text { wooden poles coated with a dense } \\
\text { tilt cloth capable of protecting from } \\
\text { any weather conditions. Tipi } \\
\text { diameter is usually from } 3 \text { to } 6 \\
\text { meters. }\end{array}$ & 2 & from 3000 \\
\hline 10 & Cuba & $\begin{array}{l}\text { Small spacious bizarre houses } \\
\text { resembling cube. }\end{array}$ & $2-4$ & from 2500 \\
\hline
\end{tabular}

In general, in Russia, the means of placing the eco-format and farm glumpings with a certain specialization (for vegetarians, bath lovers or outdoor activities) are already functioning. The average cost of accommodation in Russian glumpungams varies from 2.5 thousand to 9 thousand rubles. Overnight for two. The cost depends on the uniqueness of the supply and level of service. In the most expensive glinding, guests can meet at a helicopter, will be offered to taste rare varieties of elite white tea from bone porcelain and ten more unusual options. At the same time, prices for ordinary camping rarely exceed 1 thousand rubles.

Tourists create the most comfortable living conditions. Each guest is guaranteed to be equipped with a comfortable bed, the necessary furniture for convenient eating, storing personal belongings. Often, such buildings are equipped with not only comfortable furniture, but also a bathroom / shower, bathroom. In cases where in glinding it is impossible to install the bathroom / shower, guests are offered bathrooms. Additional services are also provided: breakfasts, room service, shuttle, towel change, Wi-Fi, modern tents for various events with all necessary equipment and equipment (tables, chairs, flipchart, projector with screen), but smoking in glinding is prohibited. The functioning period varies depending on the type of glinding, some are ready to take visitors all year round, while others operate only from May to September.

Depending on the location of the glinding, the tourist may choose fascinating classes: 
fishing, hunting, rafting, excursions, yoga, SPA, kating on quad bikes, beach holidays, skiing and much more.

Interest in Glamping can be traced among the different target audiences: since young inflexibles and bloggers who come to Glamping in content, to families with children who want to go to nature for a couple of days.

In Russia, Glamping is still little known, the geography of the distribution of such modern farm forms is not so great, but there are still examples (Table 2).

Table 2. Geography of the spread of glooping in Russia.

\begin{tabular}{|c|c|c|}
\hline № & Region & Name of objects \\
\hline 1 & Astrakhan region & $\begin{array}{c}\text { Glamping «Pier Fisherman» } \\
\text { Club fishing and hunting «ITIL» }\end{array}$ \\
\hline 2 & Kaluga region & $\begin{array}{l}\text { Glamping «Welna Eco Spa Resort» } \\
\text { Country Hotel Pineriver. } \\
\text { Glamping «Sand Camp» } \\
\text { Tourist recreation center «Far Cordon» }\end{array}$ \\
\hline 3 & Kamchatka Edge & $\begin{array}{c}\text { Glamping «Laguna» } \\
\text { Glamping «GlampStory» } \\
\text { Glamping «Kamrelax» } \\
\text { GlampingTolbachikcamp. } \\
\end{array}$ \\
\hline 4 & Krasnodar Krai & $\begin{array}{c}\text { Ecocenter Pearl (Glamping Good) } \\
\text { Glamping «Orangeneie» } \\
\text { Glomping «Scala» } \\
\text { Glampnig Hotel EcoVillalesochi } \\
\text { Sphere Glamping } \\
\text { Chill Camp Meduza. } \\
\end{array}$ \\
\hline 5 & Leningrad region & $\begin{array}{c}\text { Glamping «Lockers» } \\
\text { Glamping «Northern Crimea» } \\
\text { Gloping «Boho Camp» } \\
\text { GreenVald Park Scandinavia } \\
\text { GlampingHygge Camp. } \\
\text { A-GLAMP. } \\
\text { Glamping Hills \& Huts. } \\
\text { Glamping Shanti Home. } \\
\text { Sarozero Home. }\end{array}$ \\
\hline 6 & Moscow region & $\begin{array}{c}\text { Glamping «Expedition» } \\
\text { Glamping Konej Bor. } \\
\text { Yurt Eco Complex. }\end{array}$ \\
\hline 7 & Novgorod region & Camping «Valdai trail» \\
\hline 8 & Altai & Glamping «Chepos Park» \\
\hline 9 & Republic of Bashkortostan & Glamping Zebirsk \\
\hline 10 & Republic of Karelia & $\begin{array}{c}\text { Gloping «Camp Rock» } \\
\text { GlampingHygge Camp Karelia } \\
\text { Glamping Soul Camp. } \\
\text { Glamping Paper. } \\
\end{array}$ \\
\hline 11 & Republic of Crimea & Glamping «Mountain Resident» \\
\hline 12 & Rostov region & $\begin{array}{l}\text { Glamping «Kumja» } \\
\text { Glamping in the field }\end{array}$ \\
\hline 13 & Stavropol Territory & Glamping «Watering Lake» \\
\hline 14 & Tver region & $\begin{array}{c}\text { Glamping «Old Sig» } \\
\text { Glomping «Shiksha» } \\
\text { Glamping «Forest and Sea» } \\
\text { Glamping «Hokicamp» } \\
\text { Eco-Hotel «Novo-Okato» } \\
\text { Country resort «Kamenetski font» }\end{array}$ \\
\hline 15 & Tula region & $\begin{array}{c}\text { Glamping «Guliai City» } \\
\text { Glamping «Green Trail» } \\
\text { Ecopark Clear Field } \\
\end{array}$ \\
\hline 16 & Ulyanovsk region & Glamping «Hills» \\
\hline 17 & Khabarovsk region & Glamping «Parkhotel» \\
\hline 18 & Chelyabinsk region & Glamping «Acne Coast» \\
\hline 19 & Yaroslavl region & $\begin{array}{l}\text { Glamping «Sfera» } \\
\text { Alexandrov Stan. } \\
\text { Glamping Island } \\
\text { Park Beba } \\
\end{array}$ \\
\hline
\end{tabular}

Tourist portal Skyscanner included in the twenty 5 best glumpings and Russian. This is 
a «walk-city» in the Tula region, «Forest and the Sea» near Moscow, Leaprus in Kabardino-Balkaria, Mishkin Fairy Tale in Karelia and Ceposh Park (Altai).

This direction has become one of the most popular entertainment in 2020 in Russia, and in the future will be one of the most dynamically developing areas in the field of tourism. The Ministry of Development, with the support of Rotturism, develops a new type of subsidies to support the development of internal and inbound tourism, in particular, for the construction of glumpings and modular hotels. As of 2020, 54 million rubles are allocated from the country's federal budget annually on subsidizing entrepreneurs in the field of tourism.

Grants are designed for construction and operation of places for glinding, modular hotels and other prefab houses, recreation sites or new tourist routes.

Rostov-on-Don city - the capital of the Southern Federal District, a millionthmillionmillist on the right bank of the Don, which has uniqueness: favorable geographical location, developed transportation, economic, intellectual and cultural potentials. A large number of multi-artistic monuments, beautiful parks, modern shopping centers, Nama Other expects guests of the city. The Orthodov region and the city of Rostov-on-Don, millions of tourists are attracted annually. The Don region attracts tourists with his rich history, charming nature, hospitable inhabitants, distinctive Cossack culture.

According to the strategy of socio-economic development of the Rostov region until 2030, tourism is one of the priority branches of the Don economy. Rostov region has unique natural-climatic, cultural and historical features that create prerequisites for the development of tourism. However, in promising areas that own natural resources for the development of tourism, the tourist infrastructure of rural settlements is not sufficiently developed. This may be associated with the geographical position, the presence of various types of resources, internal and external economic factors, the lack of comfortable conditions and services.

The structure of the hotel business in the area is quite diverse. Depending on the direction, the characteristics of customer service categories and some other factors in the Rostov region distinguish such accommodation types such as: hotels, hotels, park hotels, boutique hotels, guest houses, motels, mini-hotels, hostels, furnished rooms. , Guest houses and similar institutions specially adapted for reception and organization of spending time of temporary visitors with different levels of service.

Listed above the accommodation tools in the city of Rostov-on-Don banking are more than 300 , of which $-28.4 \%$ of hotels, $0.3 \%$ of motels, $7.7 \%$ of hotels, $9.1 \%$ of guest houses, $0.6 \%$ Park hotels, $2.07 \% \mathrm{~min}$ and hotels, $0.3 \%$ of boutique hotels and $9.8 \%$ of hostels, $3.4 \%$ other means of accommodation.

The degree of security hotel numbers is one of the main criteria for the development of the hotel services market (Fig. 1). 


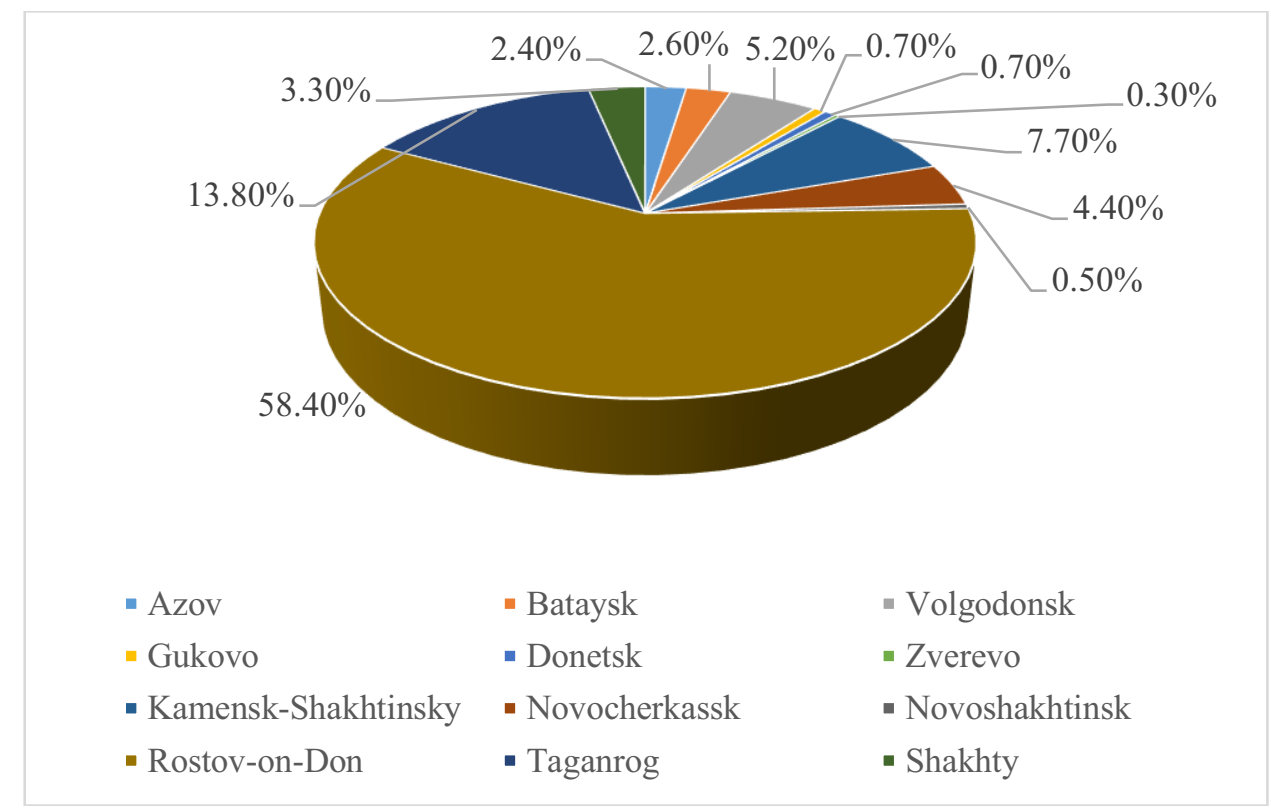

Fig. 1. Degree of security with the number foundation in the city districts of the Rostov region.

Most of the collective accommodation collective means focuses in the capital of the Southern Federal District - the city of Rostov-on-Don, where today there are more than 300 collective means of accommodating a different level, characterized by location, service, comfort, capacity, and prices.

The prospects for the development of glinding in the Rostov region are due to the presence of a huge number of unique natural places, not mastered for mass tourism, a low threshold for entering the business, rapid payback and return of investments, lack of serious restrictions and bureaucratic obstacles (Orlovsky, Kamensk-Shakhtinsky, Millerovsky, Myasnikovsky, Ust-Donetsk, etc.). However, in this direction there is a significant lack of quality proposal - a small richness of the market.

On the one hand, comfortable unity with nature, on the other, is an adequate social distance. Picturesque places to reach the adventure itself, Campfire Crash, Walking through the Forest and bathing in reservoirs. The experience of the completed season showed that the Russians are very interesting to Glepaging. This forms of the hotel farming has the future, which is facilitated by extensive expanses for development.

Thus, each type of glooping is a unique form of a hotel farm, which combines the comfort of the hotel room and rest in nature. The new format makes it possible to try something new, and remove from the city bustle. In the Russian tourism market, Glamping is a relatively new direction, but it is very promising and is actively developing.

\section{Discussion}

Orlovsky district has great opportunities for hunting and tourism. The area of hunting grounds is 220 thousand hectares, including three hunting and forest plantings: Romanovskoye, Krasnoarmeyskoye and Chapaevskoye, Rezor's reserve. In the area there are 6732 hectares of a recreational nature, of which the Natural Reserve "Rostovsky» is about 12 thousand hectares, the Manany Sanatorium - 26 hectares. The water fund is 7936 hectares, including part of the water area of Lake Manch-Gudillo - 7136 hectares. On the territory of the district there are two plots of the Rostov State Nature Reserve, including the 
Relic Salt Lake Waterland Manch Gudilo. The conditions for reproduction of a large number of plant species and animals listed in the Red Book are preserved here. On Lake Cargo, unique healing dirt and mineral water were found, in their chemical composition, similar to Tambuk mud on Kavminvoda. In P. Mannych there is a well for the production of mineral water, a tuberculous sanatorium «Manany» is functioning. In x. Lugansky has a rehabilitation center with a good base for rehabilitation and recreation of the population, organized mud. One of the leading enterprises of the district «Konnoye Plant» Donskoy is widely known due to the breeding of tribal horses of the English purebred riding breed. Another important factor in tourist attractiveness is the intersection of the area with important transport paths.

Assessment of the security coefficient of collective means of placement in the context of municipal districts, bordering the Oryolsky district optical and consistence of a sufficient proposal on the part of the hospitality industry (Fig. 2).

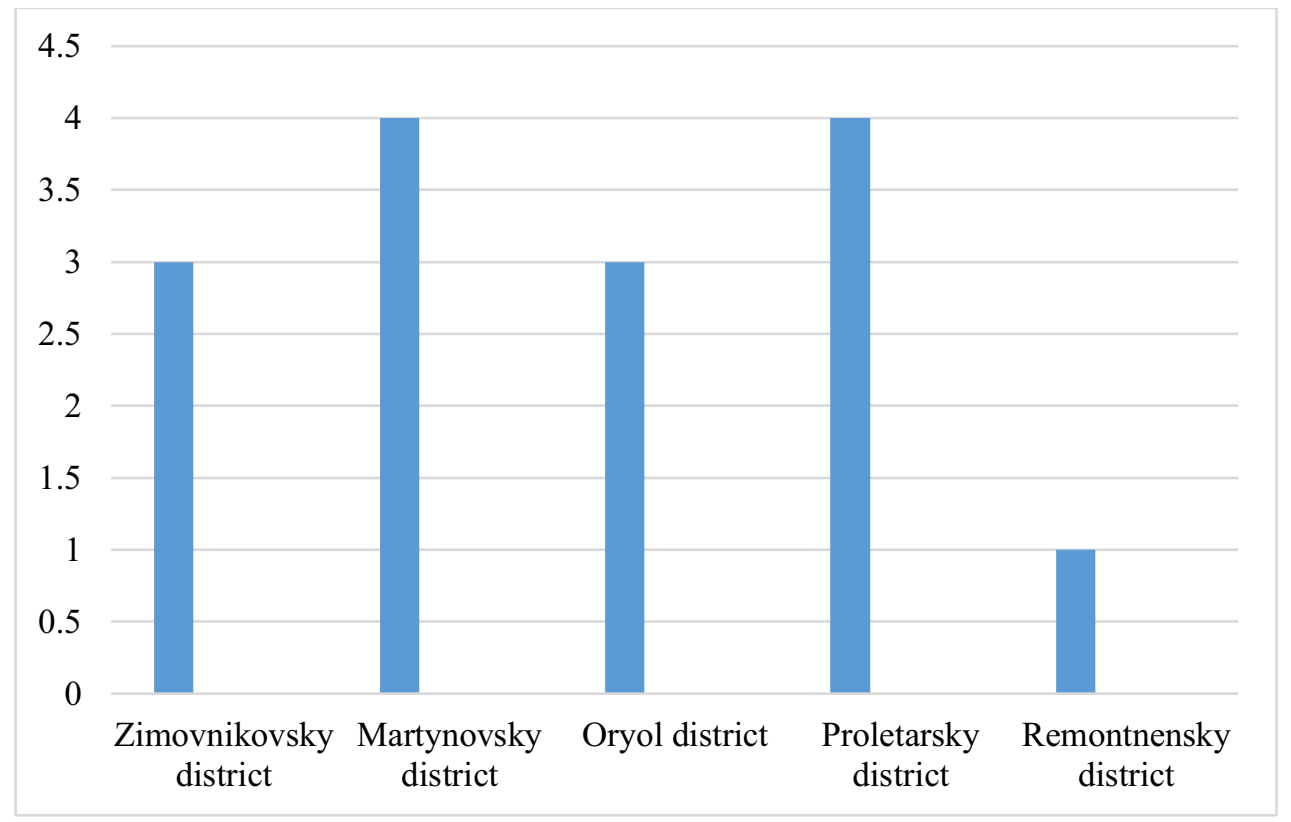

Fig. 2. Section coefficient of collective accommodation.

Thus, the project is proposed for the creation of a tourist and recreational complex in the format of a glinding park on the territory of the Oryolsky district. New for the region and the tourist industry of the Rostov region, the object will allow us to yearly take holidaymakers. The projects of enhanced bed campings attract investors due to small investments and fast payback. The project development begins with the choice of place: it must be on the "unique natural territory". It is important that the place is comfortable and safe, proximity to water, protection from strong winds and external threats is important.

For future vacationers, the total infrastructure will look like this:

-Notion in houses of different levels of comfort;

- General sanitary zones;

- IndividualExobes / Grilled houses;

- bonfire zones with mangals

- Sportsport;

-Atoparking;

-playground; 
- It is possible to accommodate with homemade pets (according to prior coordination).

Modular designs of glumpings allow you to expand the recreation center of the recreation base. In the event of an increase in demand in the season, you can place additional modular designs. As a rule, modules are accommodated near the natural water sources, or wells are made. For energy supply, generators are used, which have become very environmentally friendly and silent, possibly use of solar panels. All materials are natural (wood, metal structures, fabrics; without plastic). The construction of a small glooping with five-six living modules on average takes about a month. Also, for the construction of the project, the installation of engineering networks will be required, the organization of additional recreation areas within the camp or territory landscaping, and therefore the installation date may increase to two months.

Today, Glamping is considered a safe and rapidly paid way to invest money. There is a large potential of this business related to low competition in the market and the lack of infrastructure for recreation at remote natural territories.

Thus, staying in the Glamping Park will create a feeling of relaxing on the wake of wildlife with all the benefits of modern civilization. Also, to increase the attractiveness of recreation in the Glamping Park, exciting tourist routes in the Rostov region will be offered.

\section{Conclusions}

Russia has always been considered the most hospitable country in the world. Traditionally, the owner of the house in which the guest stopped, creates the most comfortable conditions for the temporary stay. Today, Russian culture is respected to all guests, celebrates holidays and generously giving gifts, but in many villages due to the loss of the interest of modern youth to culture, many national traditions and languages began to die. Within the framework of the Glamping project, you can also express traditions of hospitality and ethnography of the peoples of Russia.

It is such a format of tourist accommodation that becomes very relevant for the Rostov region. The glumpings will contribute to the increase in the tourist attractiveness of the most unique in the region of natural territories. They will be able to show the primetic nature of the region to the maximum number of tourists. Glamping is an excellent format for the development of environmental, cognitive and educational types of tourism.

The creation of glinding is not associated with large-scale investments and long-term construction periods, which makes them attractive for investors and small and mediumsized businesses. With the help of glumpings, it is possible to saturate the region with highquality tourism infrastructure as soon as possible.

\section{References}

1. A. Oukil, N. Channouf, A. Al-Zaidi, Journal of Hospitality and Tourism Management, 29, 60-68 (2016)

2. M. A. Köseoglu, M. Altin, E. Chan, O. F. Aladag, International Journal of Hospitality Management, 89, 102574 (2020)

3. M. S. Oborin, Tourism and Hospitality, 1, 2-17 (2018)

4. S. N. Mareeva, E. V. Zobova, L. A. Yakovleva, Socio-Economic Phenomena and Processes, 12(5), 100-105 (2017)

5. N. Y. Goryushkina, D. V. Shkurkin, A. S. Petrenko, S. Y. Demin, N. S. Yarovaya, International Review of Management and Marketing, 6(S6), 207-213 (2016) 
6. S. Karampela, D. Kavroudakis, T. Kizos, Current Issues in Tourism, 22(12), 14601479 (2019), doi:10.1080/13683500.2017.1379475

7. T.Y. Dewanti, D. Susiloningtyas, IOP Conference Series: Earth and Environmental Science, 355(1), 0120553rd, (2019), doi:10.1088/1755-1315/355/1/012055

8. S. Li, C. Li, J. Li, Asia Pacific Journal of Tourism Research, 24(11), 1079-1091 (2019), doi:10.1080/10941665.2019.1665556

9. J. Cheng, X. Jing, H. Zhenfang, Habitat International, 87, 1-10 (2019), doi:10.1016/j.habitatint.2019.03.011

10. S. Chaabouni, Journal of Destination Marketing \& Management, 11, 183-191 (2019), doi:10.1016/j.jdmm.2017.09.002

11. V. Nicula, S. Spânu, R. E. Neagu, Procedia Economics and Finance6, 530-541 (2013), doi:10.1016/S2212-5671(13)00171-8

12. D. D. Fundeanu, Procedia Economics and Finance, 23, 744-749 (2015), doi:10.1016/S2212-5671(15)00501-8

13. H. A. M. Shaffril, A. Hamzah, S. M. D. Yassin, et al., Asia Pacific Journal of Tourism Research, 3(20), 295-313 (2015), doi:10.1080/10941665.2013.877048

14. L. N. Kazmina, V. S. Makarenko, V. V. Provotorina, T. N. Grigorenko, International Journal of Economics and Business Administration, 7, 510-520 (2019), doi: $10.35808 / \mathrm{ijeba} / 297$

15. L. N. Kazmina, V. V. Provotorina, Humanities and Socio-Economic Sciences, 5(96), 109-114 (2017)

16. V. V. Provotorina, L. N. Kazmina, A. S. Petrenko, G. E. Ekinil, E3S Web of Conferences, 175, 10002 (2020), doi: 10.1051/e3sconf/202017510002

17. L. N. Kazmina, V. S. Makarenko, V.V. Provotorina, E. M. Shevchenko, E3S Web of Conferences, 175, 10001 (2020), doi:10.1051/e3sconf/202017510001

18. V. V. Provotorina, L. N. Kazmina, A. S. Petrenko, V. S. Makarenko, Lecture Notes in Civil Engineering, 130, 20-32 (2020), https://doi.org/10.1007/978-981-33-62086_3

19. G. Ekinil, V. Provotorina, A. Petrenko, L. Gorgadze, E3S Web of Conferences, 217, 05006 (2020), DOI: https://doi.org/10.1051/e3sconf/202021705006

20. E. Brooker, M. Joppe, Journal of Outdoor Recreation and Tourism, 3(4), 1-6, (2013).https://doi.org/10.1016/j.jort.2013.04.005

21. K. Grande, Journal of Outdoor Recreation and Tourism, 33, 100365 (2021), https://doi.org/10.1016/j.jort.2021.100365

22. C.A.Craig Annals of Tourism Research Available online, 103071 (2020), https://doi.org/10.1016/j.annals.2020.103071

23. A. Brochado, C. Pereira, Journal of Outdoor Recreation and Tourism, 17, 77-83, (2017), https://doi.org/10.1016/j.jort.2017.01.005 